\title{
IDENTIFIKASI TINGKAT KECURANGAN AKADEMIK DI LINGKUNGAN PERGURUAN TINGGI (Studi Pada Fakultas Ekonomi dan Bisnis Universitas Bengkulu)
}

\author{
Halimatusyadiah $^{1)}$, Aditiyawarman Nugraha ${ }^{2)}$ \\ Fakultas ekonomi dan bisnis Universitas Bengkulu ${ }^{1,2)}$ \\ halimatusyadiah@yahoo.com, aditiyawarman@yahoo.com
}

\begin{abstract}
This study aims to identify the academic fraud that occur in the environment college. Academic fraud was identified in this study is a fraud committed by students, faculty and employees. The population in this study were students of the Faculty of Economics and Business, University of Bengkulu class of 2011 - 2012. Based on the method Slovin, gained 88 people who serve as research samples. This study uses two methods of data collection, the questionnaire method and interview method. This study found that the highest fraud that has occurred is cheating "cheating" by the students with the category of "moderate", while others identified fraud in the category of "low" and "very low".
\end{abstract}

Keywords: academic cheating

\section{PENDAHULUAN}

Perguruan tinggi merupakan institusi yang didirikan dalam upaya menyelengarakan pendidikan tinggi bagi kalangan masyarakat yang bertujuan menciptakan generasi yang intelektual dan berintegritas, selain itu perguruan tinggi juga merupakan institusi yang bertanggung jawab mendidik mahasiswa agar bertindak jujur dalam setiap tindakan yang dilakukan. Namun, perguruan tinggi juga sering menjadi tempat terjadinya berbagai tindakan fraud atau kecurangan yang dapat dilakukan oleh pejabat tinggi perguruan tinggi, karyawan, dosen maupun mahasiswa.

Universitas Bengkulu merupakan perguruan tinggi negeri yang ada di kota Bengkulu. Perguruan tinggi ini didirikan pada tahun 1982, sejak saat setelah didirikan, perguruan tinggi ini juga terlibat dalam tindakan kecurangan atau fraud. Tindakan kecurangan yang sudah terekspos di media yaitu bendahara universitas yang melarikan sejumlah dana yang dimiliki oleh UNIB (Bengkulu express, 23 juni 2013). Tindakan pelarian dana tersebut dapat dikatakan tindakan korupsi yang mana merupakan salah satu unsur kecurangan yang dapat terjadi di lingkungan perguruan tinggi. Sedangkan kasus lainnya yang terjadi dibidang akademik, yakni adanya transaksi jual-beli nilai yang dilakukan oleh dosen FKIP kepada mahasiswanya (Bengkulumiol, 16 maret 2005).

Kecurangan akademik (academic fraud) merupakan kecurangan yang sering terjadi di lingkungan perguruan tinggi. Kecurangan ini terjadi bisa dilakukan oleh mahasiswa, karyawan ataupun oleh kalangan pendidik dengan secara sadar dan sengaja demi memperoleh keuntungan diri sendiri atau kelompok. Kecurangan akademik yang dilakukan oleh mahasiswa memiliki dampak negatif bagi mahasiswa tersebut dimasa mendatang. Mahasiswa yang terbiasa melakukan kecurangan akan menggantungkan hasil pencapaiannya pada orang lain bukan pada 
kemampuan dirinya sendiri. Mahasiswa melakukan kecurangan akademik karena berbagai alasan, ada yang melakukan kecurangan tersebut karena malas, tidak memiliki kepercayaan diri ataupun menginginkan nilai yang bagus. Dorongan mahasiswa untuk melakukan kecurangan akademik karena mahasiswa merasakan tingkat persaingan yang tinggi, memiliki kesempatan untuk melakukan kecurangan serta merasa tidak percaya diri terhadap kemampuannya.

Kecurangan akademik yang dilakukan oleh kalangan pendidik merupakan tindakan kecurangan yang menggunakan posisinya sebagai dosen untuk memperoleh keuntungan dengan melanggar aturan perguruan tinggi. Kecurangan akademik tersebut dapat dilakukan dari sisi bidang pengajaran dan pembelajaran, yang mana perbuatan kecurangan tersebut dilakukan secara sengaja, tersembunyi dan melawan hukum. Kecurangan yang dilakukan oleh dosen yaitu dengan menawarkan keuntungan kepada mahasiswanya dengan syarat memberikan suatu imbalan tertentu sebagai timbal baliknya.

Tindakan kecurangan yang dilakukan oleh karyawan merupakan tindakan yang dilakukan secara sengaja atau atas permintaan seseorang sehingga mereka dapat berlaku curang. Karyawan yang dapat melakukan tindakan kecurangan tersebut merupakan karyawan yang bekerja dengan sistem, mereka memegang kendali atas sistem yang ada di perguruan tinggi tersebut. Tindakan kecurangan ini terjadi karna lemahnya sistem yang dimiliki oleh perguruan tinggi sehingga dapat dimanfaatkan oleh sebagian kecil karyawan demi mengambil keuntungan bagi diri mereka sendiri.

Kecurangan akademik dalam penelitian ini terkait dengan pembelajaran dan pengajaran yang dilakukan oleh mahasiswa, dosen dan juga karyawan bagian akademik Fakultas Ekonomi dan Bisnis. Fakultas Ekonomi dan Bisnis Universitas Bengkulu memiliki tiga jurusan yang terdiri dari Akuntansi, Manajemen dan Ekonomi Pembangunan \& enam prodi yaitu prodi Ektensi, prodi D3, prodi Magister Manajemen, prodi Magister Akuntansi, prodi Magister Ekonomi Pambangunan dan prodi S3 Manajemen. Dengan memiliki jurusan beserta prodi yang cukup banyak, hal itu membuat Fakultas Ekonomi dan Bisnis memiliki jumlah mahasiswa yang banyak dibandingkan dengan fakultas lain, tetapi berbanding terbalik dengan jumlah dosen yang dimiliki oleh Fakultas Ekonomi dan Bisnis yang mana tidak sepadan dengan jumlah mahasiswa yang ada sehingga dosen yan dimiliki selain bertanggung jawab dalam mengajar mahasiswa regular, juga mengajar mahasiswa ektensi. Dengan mengajar diluar tanggung jawab tugasnya sebagai pengajar mahasiswa regular, hal tersebut dapat menimbulkan prilaku-prilaku kecurangan yang dapat dilakukan oleh dosen yakni seperti membolos mengajar, dan sebagainya. Selanjutnya dengan jumlah mahasiswa yang lebih banyak ketimbang dosen pengajar, hal ini akan berdampak pada kurangnya pengawasan pada saat ujian sehingga akan mengakibatkan akan adanya prilakuprilaku kecurangan yang dapat dilakukan oleh mahasiswa pada saat ujian berlangsung. Selain masalah ketimpangan jumlah dosen dengan mahasiswa, ada juga masalah lainnya yang dapat mengarahkan prilaku ke tindakan kecurangan, yaitu dosen Fakultas Ekonomi dan Bisnis yang memiliki profesi lain selain berprofesi sebagai dosen pengajar di jurusan yakni seperti profesi sebagai jasa akuntan dan juga jasa konsultan (baik disektor privat maupun sektor public) sehingga dengan memiliki profesi lain diluar profesi sebagai dosen pengajar maka akan membuat dosen tersebut memiliki keterbatasan waktu dalam mengajar mahasiswa dikelas dan hal itu dapat membuat dosen tersebut melakukan perbuatan prilaku kecurangan seperti membolos mengajar, dan sebagainya.

Berdasarkan hal tersebut, maka perlu adanya identifikasi kecurangan akademik (academic fraud) di lingkungan Fakultas Ekonomi dan Bisnis Universitas Bengkulu, karena tindakan kecurangan tersebut dapat berakibat pada rusaknya sistem akademik dan tentu saja akan 
menurunkan kualitas perguruan tinggi. Banyaknya tindakan yang terjadi terkait kecurangan akademik ini akan menggambarkan bahwa perguruan tinggi tersebut tidak memiliki kualitas dari output yang akan dihasilkan, hal ini tentu saja bertentangan dengan tujuan utama perguruan tinggi ini, sebagaimana visi Universitas Bengkulu yaitu menjadi universitas kelas dunia. Oleh karna itu, untuk mencapai visi tersebut perguruan tinggi ini harus memperbaiki sistem akademik agar bersih dari tindakan kecurangan yang dimulai pada tingkat fakultas. Sehingga mengidentifikasi kecurangan akademik (academic fraud) ini merupakan hal yang sangat penting dalam melihat tingkat kecurangan akademik yang terjadi serta penelitian ini bisa menjadi pedoman bagi Perguruan Tinggi ataupun Fakultas Ekonomi dan Bisnis dalam mencegah dan mengontrol tindakan - tindakan kecurangan akademik.

\section{KERANGKA TEORITIS DAN HIPOTESIS}

\section{GONE Theory}

GONE theory dikemukan oleh seorang pemikir bernama Bologne (1993) dalam Zulkarnain (2013) dimana terdapat empat faktor penyebab fraud. GONE merupakan singkatan dari huruf depan masing-masing faktor yang ia kemukakan, yakni:

1. Greed (keserakahan), berkaitan dengan adanya perilaku serakah yang secara potensial ada di dalam diri setiap orang;

2. Opportunity (kesempatan), berkaitan dengan keadaan organisasi atau instansi atau masyarakat yang sedemikian rupa sehingga terbuka kesempatan bagi seseorang untuk melakukan kecurangan terhadapnya;

3. Need (kebutuhan), berkaitan dengan faktor-faktor yang dibutuhkan oleh individu-individu untuk menunjang hidupnya yang menurutnya wajar; dan

4. Exposure (pengungkapan), berkaitan dengan tindakan atau konsekuensi yang akan dihadapi oleh pelaku kecurangan apabila pelaku ditemukan melakukan kecurangan.

\section{Fraud Triangle Theory}

Donnald E. Cressey dalam Tuanakotta (2010) mengemukakan suatu gagasan mengenai penyebab terjadinya kecurangan, gagasan tersebut dinamakan sebagai Fraud Triangle theory. Teori ini menjelaskan faktor yang melatar belakangi penyebab terjadinya kecurangan, yaitu:

1. Opportunity

Opportunity biasanya muncul sebagai akibat lemahnya pengendalian internal di organisasi tersebut. Terbukanya kesempatan ini juga dapat menggoda individu atau kelompok yang sebelumnya tidak memiliki motif untk melakukan fraud. Faktor-faktor yang menengaruhi tingkat peluang terjadinya kecurangan adalah sebagai berikut:

a. Faktor Pengendalian

Faktor pengendalian merupakan struktur pengendalian internal organisasi yang dapat mencegah dan mendeteksi tindak kecurangan. Stuktur pengendalian yang lemah akan meningkatkan risiko terjadinya kecurangan.

b. Faktor Non-pengendalian

Faktor non-pengendalian meliputi hal-hal di luar struktur pengendalian internal, yaitu:

a) Ketidakmampuan untuk menilai kualitas kinerja.

b) Kegagalan dalam menindak pelaku kecurangan.

c) Kurangnya akses informasi.

d) Pengabaian dan kurangnya kapabilitas untuk mendeteksi tindakan-tindakan illegal.

e) Kurangnya jejak audit. 


\section{Pressure}

Pressure atau tekanan pada sesorang akan membuat mereka mencari kesempatan melakukan kecurangan. Beberapa contoh pressure dapat timbul karena masalah keuangan pribadi, dan sifat-sifat buruk seperti: berjudi, narkoba, berhutang berlebihan dan tenggat waktu dan target kerja yang tidak realistis. Pressure dapat dikelompokkan menjadi 4 (empat) tipe, yaitu:

a. Tekanan Keuangan Tekanan keuangan merupakan tekanan utama yang dapat menyebabkan seseorang melakukan tindakan kecurangan.

b. Kebiasaan Buruk

Kebiasaan buruk yang menimbulkan kecanduan, seperti: berjudi, konsumsi obat terlarang, dan minuman beralkohol dapat menjadi penyebab seseorang berbuat kecurangan.

c. Tekanan Pekerjaan

Upah yang tidak memadai, kurangnya penghargaan terhadap kinerja, dan rasa khawatir akan kehilangan pekerjaan dapat menjadi pemicu tindakan kecurangan.

d. Tekanan Lainnya

Tindakan kecurangan juga dapat timbul karena tekanan-tekanan lain seperti: keinginan untuk melawan sistem atau suami/istri yang menuntut pemenuhan gaya hidup mewah.

\section{Rationalization}

Rationalization terjadi karena seseorang mencari pembenaran atas aktivitasnya yang mengandung fraud. Pada umumnya para pelaku fraud meyakini atau merasa bahwa tindakannya bukan merupakan suatu kecurangan tetapi adalah suatu yang memang merupakan haknya, bahkan kadang pelaku merasa telah berjasa karena telah berbuat banyak untuk organisasi. Dalam beberapa kasus lainnya terdapat pula kondisi dimana pelaku tergoda untuk melakukan fraud karena merasa rekan kerjanya juga melakukan hal yang sama dan tidak menerima sanksi atas tindakan fraud tersebut.

\section{Definisi Fraud}

Secara harafiah fraud didefinisikan sebagai kecurangan, namun pengertian ini telah dikembangkan lebih lanjut sehingga mempunyai cakupan yang luas. Adapun menurut The Association of Certified Fraud Examiners (ACFE) dalam Faisol (2013), fraud adalah perbuatanperbuatan yang melawan hukum yang dilakukan dengan sengaja untuk tujuan tertentu (manipulasi atau memberikan laporan keliru terhadap pihak lain) yang dilakukan orang-orang dari dalam atau luar organisasi untuk mendapatkan keuntungan pribadi ataupun kelompok secara langsung atau tidak langsung merugikan orang lain.

\section{Klasifikasi Fraud}

The Association of Certified Fraud Examiners dalam Tuanakotta (2010) mengkategorikan kecurangan dalam 3 (tiga) kelompok, yaitu :

1. Penyimpangan atas asset (Asset Missappropriation)

Asset Missappropriation meliputi penyalahgunaan/pencurian asset atau harta perusahaan atau pihak lain. Ini merupakan bentuk fraud yang paling mudah dideteksi karena sifatnya yang tangible atau dapat diukur/dihitung (defined value).

2. Kecurangan laporan keuangan ( Finacial Statement Fraud) 
Merupakan kecurangan yang dilakukan oleh manajemen perusahaan dengan cara membuat salah saji laporan keuangan secara material sehingga dapat menipu pihak-pihak pengambil keputusan yang didasarkan pada data laporan keuangan.

3. Korupsi (Corruption)

Jenis fraud ini yang paling sulit dideteksi karena menyangkut kerjasama dengan pihak lain seperti suap, pemerasan dan pemberian illegal, dimana hal ini yang merupakan jenis yang terbanyak di negara-negara berkembang yang penegakan hukumnya lemah dan masih kurang kesadaran akan tata kelola yang baik sehingga faktor integritasnya masih dipertanyakan. Fraud jenis ini sering kali tidak dapat dideteksi karena para pihak yang bekerja sama menikmati (simbiosis mutualisme) Termasuk didalamnya adalah penyalahgunaan wewenang/konflik kepentingan (conflict of interest), penyuapan (bribery), penerimaan yang tidak sah/illegal (illegal gratuities) dan pemerasan secara ekonomi ( economy extortion).

\section{Kecurangan Akademik (academic fraud)}

Lozier (2010) dalam Muslimah (2013) membagi kecurangan akademik (academik fraud) menjadi dua pengertian yaitu kecurangan (cheating) dan plagiarisme. Kecurangan (cheating) merupakan tindakan yang dilakukan oleh seseorang dengan menggunakan cara-cara yang tidak sah untuk mendapatkan keberhasilan akademis atau menghindari kegagalan akademis. Perilaku curang pada dasarnya akan mengaburkan hasil kemampuan peserta didik. Perilaku curang dibagi dalam tiga kategori yaitu (1) memberi, mengambil, atau menerima informasi tertentu, (2) menggunakan suatu alat yang dilarang, (3) memanfaatkan kelemahan orang, prosedur untuk mendapatkan keuntungan. Sedangkan plagiarisme atau sering disebut plagiat adalah penjiplakan atau pengambilan karangan, pendapat, dan sebagainya dari orang lain dan menjadikannya seolah karangan dan pendapat sendiri. Plagiat dapat dianggap sebagai tindak pidana karena mencuri hak cipta orang lain. Di dunia pendidikan, pelaku plagiarism dapat mendapat hukuman berat seperti dikeluarkan dari sekolah/perguruan tinggi (Wikipedia.org).

\section{Kategori-kategori Kecurangan Akademik (Academic Fraud)}

Menurut Colby (2006) dalam Muslimah (2013) menyatakan bahwa di Arizuna State University kategori kecurangan akademik dibagi menjadi lima kategori seperti yang dipublikasikan oleh Arizuna State University Integrity Advocates. Kategori tersebut adalah: 1. Plagiat

a. Menggunakan kata-kata atau ide orang lain tanpa menyebut atau mencantumkan nama orang tersebut.

b. Tidak menggunakan tanda kutipan dan menyebut sumber ketika menggunakan kata-kata atau ide pada saat mengerjakan laporan penelitian, makalah dari bahan internet, majalah, koran, dll.

2. Pemalsuan data, misalnya membuat data ilmiah yang merupakan data fiktif.

3. Penggandaan tugas, yakni mengajukan dua karya tulis yang sama pada dua kelas yang berbeda tanpa izin dosen/guru.

4. Menyontek pada saat ujian,seperti:

a. Menyalin lembar jawaban orang lain.

b. Menggandakan lembar soal kemudian memberikannya kepada orang lain.

c. Menggunakan teknologi untuk mencuri soal ujian kemudian diberikan kepada orang lain atau seseorang meminta orang lain mencuri soal ujian kemudian diberikan kepada orang tersebut. 


\section{Kerjasama yang salah}

a. Bekerja dengan orang lain untuk menyelesaikan tugas individual, seperti bekerjasama dengan orang lain dalam pembuatan skripsi.

b. Tidak melakukan tugasnya ketika bekerja dengan sebuah tim.

Menurut Lambert dalam Muslimah (2013) menyebutkan hal yang senada dengan Colby (2006) bahwa umumnya ada empat hal yang termasuk kecurangan akademik: (1) menyontek dengan menggunakan materi yang tidak sah dalam ujian, (2) menggunakan informasi, refensi atau data-data palsu, (3) plagiat, (4) membantu siswa lain untuk menyontek seperti membiarkan siswa lain menyalin tugasnya, memberikan kumpulan soal-soal yang sudah diujiankan, mengingat soal ujian kemudian membocorkannya.

\section{Faktor-faktor Pendorong Terjadinya Kecurangan Akademik}

Riski (2004) dalam Muslimah (2013), menjelaskan bahwa kecurangan akademik disebabkan oleh beberapa faktor, antara lain:

1. Individual

Terdapat berbagai faktor yang dapat mengidentifikasikan karakteristik individu yang dapat digunakan untuk memprediksi perilaku curang. Variabel-variabel tersebut, antara lain:

a. Usia.

Pelajar yang lebih muda lebih banyak melakukan kecurangan daripada pelajar yang lebih tua.

b. Jenis kelamin.

Siswa lebih banyak melakukan kecurangan daripada siswi. Penjelasan utama dari pernyatan tersebut dapat dijelaskan oleh teori sosialisasi peran gender yakni wanita dalam bersosialisasi lebih mematuhi aturan daripada laki-laki.

c. Prestasi akademik.

Hubungan prestasi akademik dengan kecurangan akademik bersifat konsisten. Pelajar yang memiliki prestasi belajar rendah lebih banyak melakukan kecurangan akademik daripada pelajar yang memiliki prestasi belajar tinggi. Pelajar yang memiliki prestasi rendah berusaha mencapai prestasi akademik yang lebih tinggi dengan cara berperilaku curang.

d. Pendidikan orang tua.

Pelajar yang mempunyai orang tua dengan latar pendidikan yang tinggi akan lebih mempersiapkan diri dalam mengerjakan tugas dan ujian.

e. Aktivitas ekstrakurikuler.

Pelajar yang banyak terlibat dalam kegiatan ekstrakurikuler dilaporkan lebih banyak melakukan kecurangan akademik.

2. Kepribadian

a. Moralitas.

Pelajar yang memiliki level kejujuran yang rendah akan lebih sering melakukan perilaku curang, namun penelitian yang dilakukan untuk mengetahui hubungan antara perkembangan moral dengan menggunakan tahapan moral Kohlberg menunjukkan hanya ada sedikit hubungan diantara keduanya.

b. Variabel yang berkaitan dengan pencapaian akademik. 
Variabel yang berkaitan dengan kecurangan akademik adalah motivasi, pola kepribadian dan pengharapan terhadap kesuksesan. Motivasi berprestasi memiliki hubungan yang positif dengan perilaku curang.

c. Impulsifitas, afektivitas dan variabel kepribadian yang lain. Terdapat hubungan antara perilaku curang dengan impulsifitas dan kekuatan ego. Selain hal tersebut, pelajar yang memiliki level tinggi dari tes kecemasan lebih cenderung melakukan perilaku curang.

\section{Faktor kontekstual}

a. Keanggotaan perkumpulan

Pelajar yang tergabung dalam suatu perkumpulan pelajar akan lebih sering melakukan perilaku curang. Pada perkumpulan pelajar diajarkan norma, nilai dan kemampuankemampuan yang berhubungan dengan mudahnya perpindahan perilaku curang. Pada suatu perkumpulan, penyediaan catatan ujian yang lama, tugas-tugas, tugas laboratorium dan tugas akademik lain mudah untuk dicari dan didapatkan.

a. Perilaku teman sebaya

Perilaku teman sebaya memiliki pengaruh yang penting terhadap kecurangan akademik. Hubungan tersebut dijelaskan dengan menggunakan teori pembelajaran sosial dari Bandura dan teori hubungan perbedaan dari Edwin Sutherland. Teori-teori tersebut mengemukakan bahwa perilaku manusia dipelajari dengan mencontoh perilaku individu lain yang memiliki perilaku menyimpang akan berpengaruh terhadap peningkatan perilaku individu yang menirunya.

b. Penolakan teman sebaya terhadap perlaku curang

Penolakan teman sebaya terhadap perilaku curang merupakan salah satu faktor penentu yang penting dan dapat berpengaruh terhadap perubahan perilaku curang pada pelajar.

4. Faktor situasional

a. Pelajar terlalu banyak, kompetisi dan ukuran kelas

Pelajar yang belajar terlalu banyak dan menganggap dirinya berkompetisi dengan pelajar lain lebih cenderung melakukan kecurangan dibandingkan pelajar yang tidak belajar terlalu banyak.

c. Lingkungan ujian

Pelajar lebih cenderung melakukan kecurangan di dalam ujian jika pelajar tersebut berpikir bahwa hanya ada sedikit resiko ketahuan ketika melakukan kecurangan.

Menurut Matindas (2010) dalam Purnamasari (2013), memaparkan beberapa hal yang mendorong terjadinya kecurangan akademik, antara lain:

1. Individu yang bersangkutan tidak tahu bahwa perbuatan tersebut tidak boleh dilakukan.

2. Individu yang bersangkutan tahu hal tersebut tidak boleh dilakukan tetapi yakin bahwa individu tersebut dapat melakukannya tanpa ketahuan.

3. Individu yang bersangkutan:

a). Tahu hal tersebut tidak boleh dilakukan

b). Tidak yakin bahwa perbuatan tersebut tidak akan diketahui, tetapi individu tersebut tidak melihat kemungkinan lain untuk mencapai tujuan utamanya (lulus atau mendapat nilai kredit untuk kenaikan pangkat), dan berharap agar perbuatannya tidak ketahuan.

4. Individu yang bersangkutan tidak percaya bahwa ancaman sanksi akan benar-benar dilakukan.

5. Individu yang bersangkutan tidak merasa malu apabila perbuatannya diketahui orang lain. 


\section{Peraturan Kewajiban dan Larangan Bagi Dosen dan Karyawan}

Ada beberapa peraturan yang dibuat oleh pemerintah RI guna mengatur kewajiban dan larangan bagi kalangan dosen serta karyawan di perguruan tinggi, adapun peraturannya yaitu sebagai berikut

\section{d. PP Nomor 53 tahun 2010}

PP nomor 53 tahun 2010 tentang Disiplin Pegawai Negeri menjelaskan beberapa kewajiban dan larangan bagi karyawan dan dosen, yaitu sebagai berikut:

\section{e. Pasal 3}

Setiap PNS wajib:

a. Ayat 9: Bekerja dengan jujur, tertib, cermat, dan bersemangat untuk kepentingan negara;

b. Ayat 10: Melaporkan dengan segera kepada atasannya apabila mengetahui ada hal yang dapat membahayakan atau merugikan negara atau Pemerintah terutama di bidang keamanan, keuangan, dan materiil;

c. Ayat 11: masuk kerja dan menaati ketentuan jam kerja;

d. Ayat 12: mencapai sasaran kerja pegawai yang ditetapkan;

b) Pasal 4

Setiap PNS dilarang:

a. Ayat 1: menyalahgunakan wewenang;

b. Ayat 2: menjadi perantara untuk mendapatkan keuntungan pribadi dan/atau orang lain dengan menggunakan kewenangan orang lain;

c. Ayat 6: melakukan kegiatan bersama dengan atasan, teman sejawat, bawahan, atau orang lain di dalam maupun di luar lingkungan kerjanya dengan tujuan untuk keuntungan pribadi, golongan, atau pihak lain, yang secara langsung atau tidak langsung merugikan negara;

d. Ayat 8: menerima hadiah atau suatu pemberian apa saja dari siapapun juga yang berhubungan dengan jabatan dan/atau pekerjaannya;

e. Ayat 11 : menghalangi berjalannya tugas kedinasan;

\section{PP nomor 37 pasal 29 tahun 2009}

PP nomor 37 pasal 29 tahun 2009 tentang dosen menjelaskan tentang kewajiban dosen dalam memberikan nilai kepada tiap mahasiswa yang diajarkannya, yang rinciannya sebagai berikut:

f. Ayat 1: Dosen memiliki kebebasan dalam memberikan penilaian dan menentukan kelulusan mahasiswa sesuai dengan kriteria dan prosedur yang ditetapkan oleh perguruan tinggi dan peraturan perundang-undangan.

b. Ayat 2: Penilaian dan penentuan kelulusan mahasiswa sebagaimana dimaksud pada ayat (1), dilakukan dosen secara objektif, transparan, dan akuntabel.

\section{Undang-undang no 14 pasal 67 tahun 2005}

UU no 14 pasal 67 tahun 2005 menjelaskan hukuman bagi para dosen yang telah melakukan kecurangan, yaitu sebagai berikut:

Ayat 2: Dosen dapat diberhentikan tidak dengan hormat dari jabatan sebagai dosen karena:

a. Melanggar sumpah dan janji jabatan;

b. Melanggar perjanjian kerja atau kesepakatan kerja bersama; atau

c. Melalaikan kewajiban dalam menjalankan tugas selama 1 (satu) bulan atau lebih secara terus-menerus.

\section{Kerangka Teoritis}

Pada gambar dibawah dapat menunjukkan suatu kerangka pemikiran yang akan diteliti sebagai berikut: 


\section{Gambar 1. Kerangka Penelitian}

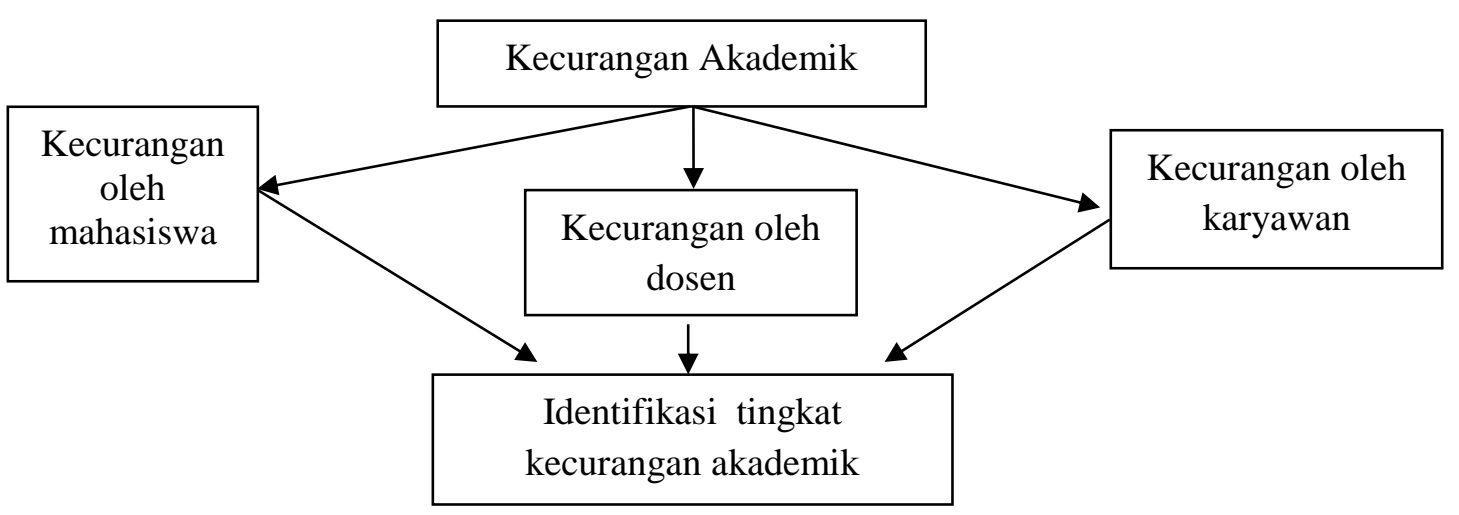

\section{METODE PENELITIAN}

\section{Subjek dan Objek Penelitian}

Subjek penelitian adalah subjek yang dituju untuk diteliti oleh peneliti. Objek penelitian adalah obyek yang dijadikan penelitian atau yang menjadi titik perhatian suatu penelitian. Dalam penelitian ini yang menjadi subjek penelitian adalah mahasiswa Fakultas Ekonomidan Bisnis angkatan 2011-2012, karena dalam penelitian ini mahasiswa angkatan 2011-2012 sedang melakukan penelitian yang berhubungan dengan indikator yang akan diteliti oleh peneliti. Sedangkan objek penelitian ini adalah Fakultas Ekonomi dan Bisnis Universitas Bengkulu.

\section{Sumber Data}

Sumber data dalam penelitian ini adalah data primer. Data primer merupakan data penelitian yang diperoleh secara langsung dari sumber asli. Dalam penelitian ini, data diperoleh langsung dari responden dengan mengajukan beberapa pernyataan yang terdapat dalam kuesioner dan mengajukan beberapa pertanyaan secara langsung (wawancara) dengan bertatap muka terkait fraud academic pada mahasiswa S1 Fakultas Ekonomi angkatan 2011-2012 yang sedang menjalankan penelitian.

\section{Popolasi dan Sampel Penelitian}

Populasi dalam penelitian ini adalah mahasiswa Fakultas Ekonomi dan Bisnis yang terdiri dari mahasiswa S1 jurusan Akuntansi angkatan 2011-2012, mahasiswa S1 jurusan Manajemen angkatan 2011-2012, mahasiswa S1 jurusan Studi Pembangunan angkatan 2011-2012, mahasiswa Ekstensi Ekonomi angkatan 2011-2012.

Sampel yang diambil sebagai responden dalam penelitian ini adalah sebanyak 88 orang mahasiswa. Untuk mengambil jumlah sampel peneliti menggunakan rumus Slovin, yaitu sebagai berikut:

$$
\mathrm{n}=\frac{\mathrm{N}}{1+\mathrm{N}(\alpha)^{2}}
$$

\section{Keterangan:}

n : Jumlah sampel minimal

$\mathrm{N} \quad$ : Jumlah Populasi 
$\alpha$ : Nilai kritis (batasan ketelitian) yang diinginkan (persen kelonggaran ketidaktelitian karena pengambilan sampel populasi). Dalam penelitian ini nilai $\alpha$ adalah sebesar 0,1 atau $10 \%$.

Dengan menggunakan tingkat kesalahan 10\%,maka ukuran sampel dapat dihitung sebagai berikut:

$$
\begin{aligned}
\mathrm{n} & =\frac{757}{1+757(\mathrm{o}, 1)^{2}} \\
& =757 / 8,57 \quad=88,33 \text { dibulatkan menjadi } 88 \text { orang }
\end{aligned}
$$

Berdasarkan rumus Slovin diatas, maka sampel dalam penelitian ini sebanyak 88 orang mahasiswa yang terdiri dari mahasiswa Ekstensi Ekonomi angkatan 2011-2012 dan mahasiswa S1 reguler Fakultas Ekonomi angkatan 2011-2012.

\section{Metode Pemilihan Sampel}

Pemilihan sampel dalam penelitian ini yaitu menggunakan tehnik Convenience Sampling. Metode ini memilih sampel dari elemen populasi (orang atau kejadian) yang datanya mudah diperoleh peneliti. Elemen populasi yang dipilih sebagai subjek sampel adalah tidak terbatas sehingga peneliti memiliki kebebasan untuk memilih sampel yang paling cepat dan mudah (Sanusi, 2011). Melalui teknik convenience sampling sampel diambil/dipilih berdasarkan kemudahan dan sesuai dengan kriteria penelitian.

\section{Metode Pengumpulan Data Penyebaran Kuesioner}

Data yang digunakan dalam penelitian ini diperoleh dengan menggunakan metode pengumpulan data melalui penyebaran kuesioner. Kuesioner merupakan daftar pernyataan yang akan diisi oleh reponden, yaitu terkait fraud academic. Dalam penelitian ini kuesioner dibuat kedalam 36 pernyataan dengan menggunakan pengukuran skala Likert dengan poin 1 sampai 5. Kuesioner yang akan dibagikan/disebarkan dalam penelitian ini yaitu sebanyak 88 kuesioner. Kuesioner tersebut akan diberikan pada mahasiswa Fakultas Ekonomi dan Bisnis yang telah dijadikan sebagai sampel dalam penelitian ini. Setelah kuesioner dibagikan, peneliti akan langsung mengambilnya dari responden. Dari hasil kuesioner ini nanti, diharapkan dapat menunjukan hal yang sebenarnya mengenai tingkat kecurangan akademik yang terjadi di Fakultas Ekonomi dan Bisnis Universitas Bengkulu.

\section{Wawancara}

Pada penelitian ini, peneliti juga menggunakan metode wawancara dalam usaha memperoleh data pendukung terkait fraud academic yang terjadi di Fakultas Ekonomi dan Bisnis. Teknik wawancara ini dilakukan secara formal dan intensif sehingga akan mampu memperoleh informasi sebanyak mungkin secara jujur dan detail. Dalam penelitian ini, peneliti menggunakan wawancara dengan pertanyaan terstruktur, dimana peneliti menggunakan pedoman wawancara yang telah tersusun. Dalam teknik ini, peneliti menggunakan alat bantu seperti tape recorder. Pada penelitian ini, peneliti menggunakan wawancara kepada 5 informan yang dipilih dari 88 responden, wawancara tersebut akan memperkaya informasi tentang kecurangan akademik yang terjadi di Fakultas Ekonomi dan Bisnis. Penentuan informan pada penelitian ini didasarkan pada hasil kuesioner yang ditelah dianalisa oleh peneliti sebelumnya

Pengumpulan data dengan tehnik wawancara ini akan menghasilkan data-data berupa catatan hasil wawancara yang dapat berupa transkrip dari keseluruhan wawancara. Dari 
wawancara mendalam ini, peneliti berharap dapat menambah serta memperkaya informasi terkait kecurangan akademik tersebut.

\section{Uji Kualitas Data}

Validitas adalah suatu ukuran yang menunjukkan tingkat kevalidan atau kesahihan suatu instrument. Suatu instrument yang valid mempunyai validitas tinggi dan sebaliknya bila tingkat validitas rendah maka instrument tersebut kurang valid. Dari hasil uji validitas yang telah dilakukan 12 variabel menunjukan kevalidan dan Uji Reliabilitas digunakan untuk mengukur apakah jawaban responden terhadap pertanyaan dalam kuesioner konsisten atau stabil dari waktu ke waktu. Pada penelitian ini, uji reliabilitas dilakukan dengan uji statistik Cronbach Alpha. Hasil uji Reliabilitas yang telah dilakukan juga menunjukkan bahwa 12 variabel bersifat realibel.

\section{HASIL PENELITIAN}

\section{Pembahasan}

Prilaku kecurangan pada akademik dapat dilakukan oleh kalangan mahasiswa, dosen dan juga oleh karyawan bagian akademik. Prilaku kecurangan tersebut dapat terjadi disebabkan oleh berbagai alasan pelaku dalam melakukan tindakan kecurangan, seperti adanya kesempatan dan juga tekanan sehingga membuat pelaku melakukan tindakan kecurangan. Prilaku kecurangan akademik yang terjadi pada Fakultas Ekonomi dan Bisnis di Universitas Bengkulu berada pada kategori sangat rendah, rendah dan juga sedang. Hal ini dapat diketahui dari nilai rata-rata dari beberapa indikator kecurangan akademik. Dari hasil penelitian yang telah dilakukan sebelumnya, dapat dilihat bahwa sebagian besar indikator pada prilaku kecurangan akademik berada pada kategori sangat rendah yakni dengan memiliki nilai rata-rata dibawah 1,80. Meskipun sebagian besar dari indikator kecurangan akademik menunjukkan berada pada kategori "sangat rendah" namun dari data yang terlihat ada beberapa indikator yang berada pada kategori "rendah" dengan nilai rata-rata antara 1,81-2,60 dan juga kecurangan yang berada pada kategori "sedang" dengan nilai rata-rata antara 2,61-3,40. Adapun tingkat kecurangan tiap-tiap indikator dari fraud academic yaitu dijelaskan sebagai berikut :

1. Indikator Dari Kecurangan Akademik yang dilakukan Oleh Mahasiswa

a. Menyontek

Prilaku kecurangan pada indikator menyontek dapat berupa melihat jawaban teman sebangku atau sekelas, membawa catatan yang dilarang dalam ujian ataupun membuka buku pada saat ujian berlangsung. Indikator kecurangan dengan menyontek ini termasuk kedalam kategori "sedang". hal ini berdasarkan pada nilai rata-rata yang diperoleh dari penyebaran kuesioner kepada responden bahwa indikator menyontek memiliki nilai rata-rata sebesar 2,64. Dari nilai rata-rata tersebut membuktikan bahwa sebagian besar responden pernah melakukan prilaku menyontek pada saat ujian. Sedangkan dari hasil wawancara yang telah dilakukan kepada informan sebagai informasi tambahan dalam penelitian ini, informan mengatakan bahwa perbuatan menyontek yang kerap dilakukan disebabkan karena mereka memperoleh kesempatan dalam melakukan perbuatan kecurangan, hal tersebut dikarenakan kurangnya pengawasan saat ujian yang dilakukan oleh dosen pengawas.

\section{b. Membeli Soal}

Tindakan kecurangan akademik yang dapat dilakukan oleh kalangan mahasiswa di lingkungan perguruan tinggi yaitu membeli soal ujian kepada pihak tertentu. Tindakan 
kecurangan ini merupakan tindakan yang dilakukan oleh mahasiswa dengan membeli soal ujian kepada pihak tertentu agar dapat memperoleh soal ujian yang akan diujiankan, dengan begitu ia dapat menjawab semua pertanyaan dengan baik pada saat ujian berlangsung.

Berdasarkan dari hasil penyebaran kuesioner, indikator ini memiliki nilai rata-rata sebesar 1,26, yang membuktikan bahwa kecurangan ini tidak terjadi di Lingkungan Fakultas Ekonomi dan Bisnis. Hal ini didukung dari hasil wawancara kepada kelima informan bahwa tidak ada informan yang membeli soal ujian kepada pihak tertentu agar mendapatkan nilai yang bagus. Maka hal tersebut dapat disimpulkan bahwa mahasiswa Fakultas Ekonomi dan Bisnis dalam melakukan kecurangan akademik pada indikator membeli soal ujian berada pada kategori "sangat rendah".

\section{c. Membeli Nilai}

Prilaku kecurangan selanjutnya yang dapat dilakukan oleh mahaisswa yaitu kecurangan akademik dengan membeli nilai.. Kecurangan akademik dengan membeli nilai dilakukan oleh mahasiswa dengan memberikan imbalan tertentu kepada dosen tertentu dengan hasil mahasiswa tersebut mendapatkan nilai yang bagus. Data penelitian menunjukkan bahwa kecurangan ini merupakan kecurangan yang tidak pernah terjadi, hal ini dibuktikan dari nilai rata-rata yang dimiliki yaitu sebesar 1,10 atau berada pada kategori "sangat rendah". Hal ini sesuai dengan hasil wawancara kepada informan bahwa informan tidak pernah melakukan perbuatan kecurangan dengan membeli nilai kepada dosen agar mendapatkan nilai yang bagus.

\section{d.Plagiat}

Prilaku kecurangan akademik yang dilakukan oleh kalangan mahasiswa berikutnya yaitu prilaku kecurangan dengan plagiat. Prilaku kecurangan ini dapat berupa, seperti mengutip katakata dari internet ataupun kata-kata yang terdapat dibuku yang dimasukkan kedalam penelitian (skripsi) tanpa menyatakan sumbernya. Pada prilaku kecurangan yang dilakukan oleh mahasiswa dengan plagiat ini memiliki nilai rata-rata sebesar 2,22, hal ini berdasarkan dari hasil penyebaran kuesioner kepada responden. Hal tersebut membuktikan bahwa kebanyakan responden tidak melakukan prilaku kecurangan dengan plagiat ini tetapi walaupun demikian ada sebagian kecil responden yang melakukan perbuatan kecurangan dengan mengutip kata-kata dari internet/buku tanpa menyatakan sumber aslinya. Sedangkan dari hasil wawancara kepada kelima informan, bahwa informan melakukan perbuatan plagiat dikarenakan mencantumkan sumber asli bukan merupakan sesuatu yang penting, hal ini berdasarkan pada informasi yang diperoleh lewat wawancara kepada salah satu informan bahwa ia akan mencantumkan sumber asli ketika diminta oleh dosen dan juga ketika sumber asli dari kata-kata yang dikutip mudah diperoleh. Dengan demikian jika dikaitkan dengan teori fraud triangle bahwa kecurangan ini dapat terjadi disebabkan karena ada faktor kesempatan. Yakni mahasiswa yang melakukan prilaku kecurangan dengan plagiat memperoleh kesempatan dikarenakan sedikitnya perhatian dari dosen pembimbing terhadap referensi yang digunakan didalam penelitian mahasiswa tersebut.

\section{e.Meminta Bantuan Orang Lain Dalam Pembuatan Skripsi}

Prilaku kecurangan akademik yang dapat terjadi di Lingkungan Perguruan Tinggi yang dilakukan oleh mahaisswa yaitu kecurangan dengan meminta bantuan kepada orang lain dalam penyelesaian skripsi. Prilaku kecurangan dengan meminta bantuan orang lain (skripsi) adalah kecurangan yang dilakukan oleh mahasiswa dengan membayar/meminta seseorang/pihak tertentu agar dapat menyelesaikan skripsi milikinya sehingga skripsinya dapat terselesaikan 
dengan bantuan pihak tersebut. Dari data yang telah diperoleh dari penyebaran kuesioner bahwa kecurangan ini memiliki nilai rata-rata sebesar 1,44, atau berada pada kategori "sangat rendah", sehingga hal ini membuktikan bahwa kecurangan ini tidak terjadi di Lingkungan Fakultas Ekonomi dan Bisnis. Hal tersebut diperjelas dari hasil wawancara kepada kelima informan bahwa tidak ada dari informan yang pernah yang melakukan kecurangan dengan membayar/meminta pihak tertentu agar dapat menyelesaikan penelitiannya. Adapun dari pernyataan informan bahwa ia hanya meminta bantuan pihak tertentu hanya dalam hal seperti menggunakan SPSS ataupun meminta mencarikan jurnal penelitian kepada sesama teman mahasiswa.

\section{Indikator Dari Kecurangan Akademik Yang Dilakukan Oleh Dosen}

a. Membiarkan Mahasiswa Menyontek

Kecurangan akademik yang dilakukan oleh dosen yaitu berupa membiarkan mahasiswa menyontek saat ujian. Prilaku membiarkan dalam hal ini contohnya seperti membiarkan mahasiswa melakukan perbuatan yang dilarang pada saat ujian berlangsung yaitu melihat jawaban teman, membaca contekan/materi yang dilarang dan membaca buku perkuliahan yang diujiankan pada saat ujian. Dari data yang diperoleh dari hasil penyebaran kuesioner menyatakan bahwa prilaku kecurangan ini memiliki nilai rata-rata sebesar 1,75, sehingga hal tersebut membuktikan bahwa kecurangan ini tidak terjadi di Lingkungan Fakultas Ekonomi dan Bisnis. Hal ini sesuai dengan hasil wawancara yang telah dilakukan bahwa kecurangan akademik ini tidak pernah dilakukan oleh dosen yang mengajar mereka. Adapun dari pernyataan informan bahwa pada saat ujian ada beberapa dosen yang mengizinkan membuka buku perkuliahan, hal itu dikarenakan materi ujian yang cukup sulit. Tetapi hal tersebut bukan merupakan prilaku kecurangan yang dilakukan oleh dosen melainkan metode ujian yang bersifat open book yang dilakukan oleh dosen pengampu matakuliah tersebut. Sehingga dengan demikian prilaku kecurangan dengan membiarkan mahasiswa melakukan prilaku menyontek ini tidak terjadi di Lingkungan Fakultas Ekonomi dan Bisnis.

\section{b.Menjual Soal Ujian}

Prilaku kecurangan berikutnya yaitu kecurangan akademikyang dilakukan oleh kalangan dosen dengan menjual soal ujian kepada mahasiswanya. Prilaku ini dilakukan oleh dosen dengan sengaja membocorkan soal ujian yang akan diujiankan kepada mahasiswa dengan meminta imbalan tertentu kepada mahasiswa tersebut. Pada data penelitian yang telah diperoleh dari hasil penyebaran kuesioner bahwa kecurangan ini memiliki nilai rata-rata sebesar 1,16, atau berada pada kategori "sangat rendah", sehingga hal tersebut menunjukkan bahwa kecurangan akademik dengan indikator ini tidak pernah terjadi. Hal ini juga sesuai dengan hasil wawancara yang telah dilakukan kepada kelima informan, bahwa kecurangan ini merupakan kecurangan yang tidak pernah dilakukan oleh kalangan dosen. Dengan demikian dapat disimpulkan bahwa kecurangan akademik dengan menjual soal ujian yang dilakukan oleh dosen tidak terjadi di Lingkungan Fakultas Ekonomi dan Bisnis.

\section{c.Menjual Nilai}

Prilaku kecurangan akademik lainnya adalah kecurangan akademik dengan indikator menjual nilai yang dilakukan oleh kalangan dosen. Kecurangan ini merupakan kecurangan yang dilakukan oleh dosen dengan memberikan nilai bagus dari matakuliah yang diajarkannya kepada mahasiswa dengan syarat menerima imbalan tertentu yang menguntungkan bagi dosen tersebut. 
Pada prilaku kecurangan ini nilai rata-rata yang diperoleh sebesar 1,11, yang membuktikan bahwa kecurangan dengan indikator dengan menjual nilai ini merupakan kecurangan yang tidak pernah terjadi dilingkungan Fakultas Ekonomi dan Bisnis. Hal ini juga didukung dari hasil wawancara bahwa kecurangan ini merupakan kecurangan yang tidak pernah dilakukan oleh kalangan dosen. Sehingga dengan demikian hal ini membuktikan bahwa dosen dilingkungan Fakultas Ekonomi dan Bisnis sangat objektif dalam memberikan nilai kepada para mahasiswanya.

\section{d.Tidak Masuk Mengajar}

Indikator kecurangan akademikyang dilakukan oleh kalangan dosen yaitu dengan prilaku tidak masuk mengajar dikelas. Prilaku kecurangan akademik yang dilakukan oleh dosen tersebut berupa melepaskan tanggung jawabnya sebagai pengajar dengan tidak mengajar mahasiswa dikelas sesuai jadwal yang telah ditetapkan.

Pada prilaku kecurangan ini, memiliki nilai rata-rata sebesar 1,98, hal ini membuktikan bahwa pada kecurangan ini sebagian kecil dosen melakukan perbuatan kecurangan dengan meninggalkan tanggung jawabnya yang tidak masuk mengajar dikelas. Hal ini diperjelas dari hasil wawancara yang kepada kelima informan, bahwa ada beberapa dosen yang melakukan tindakan kecurangan ini, dosen tersebut biasanya memiliki kesibukan diluar kampus atau memiliki urusan lain sehingga kelas ditinggalkan begitu saja. Dengan demikian jika dikaitkan pada Teori fraud triangle bahwa kecurangan ini dapat terjadi dikarenakan adanya faktor kesempatan yang dimiliki oleh dosen tersebut, hal ini disebabkan karena kurangnya pengawasan serta pengendalian yang dilakukan oleh pihak fakultas sehingga dengan demikian dosen tersebut memperoleh kesempatan untuk dapat melakukan perbuatan kecurangan dengan meninggalkan tanggung jawabnya sebagai pengajar.

\section{e. Memberikan Bantuan dalam Pembuatan Skripsi}

Pada indikator kecurangan dengan memberikan bantuan pembuatan skripsi yang dilakukan oleh kalangan dosen berada pada kategori sangat rendah. Pada prilaku kecurangan akademik ini dosen memberikan bantuan dalam pembuatan skripsi kepada mahasiswanya. Pada kecurangan ini dosen memberikan bantuan kepada mahasiswa dengan cara membuatkan skripsi dari mahasiswa kemudian dari tindakan kecurangan ini dosen tersebut memperoleh berupa imbalan dari mahasiswa tersebut.

Data dari hasil penyebaran kuesioner yang mana pada indiaktor ini memiliki nilai ratarata sebesar 1,09, yang menunjukkan bahwa kecurangan dengan indikator ini tidak terjadi di Fakultas Ekonomi dan Bisnis. Hal ini juga didukung dari hasil wawacara bahwa kelima informan memberikan pernyataan bahwa tidak ada dosen yang melakukan perbuatan kecurangan dengan memberikan bantuan pembuatan skripsi mahasiswa.

\section{f. Meminta Imbalan dalam Membimbing (skripsi)}

Prilaku kecurangan akademik berikutnya yaitu memberikan bantuan dalam pembuatan skripsi yang dilakukan oleh dosen. Pada kecurangan ini dosen memberikan bantuan kepada mahasiswa dengan cara membuatkan skripsi dari mahasiswa kemudian dari tindakan kecurangan ini dosen tersebut memperoleh berupa imbalan dari mahasiswa tersebut. Data dari hasil penyebaran kuesioner yang mana pada indiaktor ini memiliki nilai rata-rata sebesar 1,09, yang menunjukkan bahwa kecurangan dengan indikator ini tidak terjadi di Fakultas Ekonomi dan Bisnis. Hal ini juga didukung dari hasil wawacara bahwa kelima informan memberikan 
pernyataan bahwa tidak ada dosen yang melakukan perbuatan kecurangan dengan memberikan bantuan pembuatan skripsi mahasiswa.

\section{Kecurangan Akademik Yang Dilakukan Oleh Karyawan}

Prilaku kecurangan akademik berikutnya yaitu kecurangan dengan merubah nilai matakuliah yang dapat dilakukan oleh karyawan akademik. Kecurangan ini merupakan kecurangan yang dapat dilakukan oleh karyawan akademik dengan merubah nilai dari mahasiswa sehingga ia dapat memperoleh suatu keuntungan dari tindakan tersebut. Dari data yang telah diperoleh bahwa kecurangan ini memiliki nilai rata-rata sebesar 1,07, yang membuktikan bahwa kecurangan ini tidak terjadi di Lingkungan Fakultas Ekonomi dan Bisnis. Berdasarkan pada hasil wawancara kepada kelima informan tidak ada karyawan akademik yang mengubah nilai dari mahasiswa.

\section{PENUTUP}

\section{Simpulan}

Penelitian ini bertujuan untuk mengetahui tingkat kecurangan dari tiap-tiap indikator dari kecurangan akademik yang dilakukan oleh mahasiswa, dosen dan juga karyawan dilingkungan Fakultas Ekonomi dan Bisnis Universitas Bengkulu. Berdasarkan hasil pembahasan, simpulan dari penelitian ini adalah:

(1) Pada Kecurangan Akademik yang dilakukan oleh mahasiswa, prilaku menyontek merupakan prilaku kecurangan tertinggi tingkat terjadinya dibandingkan kecurangan akademik lainnya yang dapat dilakukan oleh kalangan mahasiswa yang mana pada kecurangan ini berada pada kategori sedang, kecurangan tersebut dapat terjadi dikarenakan lemahnya pengawasan oleh dosen pada saat ujian berlangsung sehingga menimbulkan kesempatan bagi mahasiswa dalam melakukan kecurangan.pada saat ujian berlangsung

(2) Pada Kecurangan Akademik yang dilakukan oleh dosen sebagian besar prilaku kecurangan berada pada kategori rendah dan juga sangat rendah. Adapun prilaku yang berada pada kategori rendah yaitu pada prilaku tidak masuk mengajar dikelas yang dilakukan oleh dosen (tanpa keterangan apapun). Pada kecurangan tersebut tingkat terjadinya berada pada kategori rendah artinya tidak terlalu mengkhawatirkan tetapi meskipun demikian perlu sedikit perhatian agar dapat memperbaiki sistem pembelajaran di Lingkungan Fakultas Ekonomi dan Bisnis Universitas Bengkulu.

(3) Pada Kecurangan Akademik yang dilakukan oleh karyawan bagian akademik yaitu prilaku kecurangan dengan mengubah nilai matakuliah dari mahasiswa. Pada prilaku kecurangan ini tidak terlalu perlu mendapatkan perhatian khusus karena pada kecurangan ini tingkat terjadinya berada pada kategori sangat rendah atau prilaku kecurangan ini tidak pernah terjadi di Lingkungan Fakultas Ekonomi dan Bisnis Universitas.

\section{Implikasi Penelitian}

(1) Bagi Fakultas Ekonomi dan Bisnis hendaknya meningkatkan Pengendalian serta pengawasan kepada mahasiswa agar tindakan kecurangan-kecurangan yang dapat dilakukan oleh mahasiswa, seperti menyontek pada saaat ujian dapat diturunkan tingkat terjadinya ke kategori sangat rendah, sehingga kualitas output dari Fakultas Ekonomi dan Bisnis menjadi lebih baik. 
(2) Bagi Unit Pengendalian Mutu hendaknya penelitian ini menjadi bahan acuan dalam menyusun sistem kendali mutu khususnya bidang pembelajaran di Fakultas Ekonomi dan Bisnis.

\section{Keterbatasan Penelitian}

Penelitian ini memiliki keterbatasan yang memerlukan perbaikan dan pengembangan dalam penelitian selanjutnya. Keterbatasan dalam penelitian ini adalah:

(1) Pada metode wawancara yang dijadikan informan hanya sebanyak 5 orang mahasiswa sehingga mengakibatkan peneliti hanya memperoleh sedikit informasi mengenai kecurangan akademik yang terjadi dilingkungan Fakultas Ekonomi dan Bisnis.

(2) Responden pada penelitian ini adalah mahasiswa regular dan mahasiswa ekstensi, namun lebih banyak didominasi oleh mahasiswa reguler sedangkan mahasiswa ektensi yang berpartisipasi didalam penelitian ini hanya 18 orang dari 88 responden. Sehingga hasil penelitian tidak menggambarkan tingkat kecurangan secara keseluruhan. Hal tersebut dikarenakan mahasiswa ektensi sebagian besar sudah mempunyai pekerjaan sehinggga membuat mereka mempunyai sedikit waktu untuk belajar maka tekanan untuk melakukan kecurangan cukup tinggi.

\section{Saran}

Berdasarkan hasil penelitian yang telah dilakukan, diajukan saran untuk penelitian selanjutnya antar lain:

(1) Memperbanyak jumlah informan sehingga informasi yang didapatkan lebih banyak mengenai kecurangan akademik.

(2) Lebih banyak menggambil responden penelitian dari mahasiswa ektensi demi mendapatkan gambaran secara keseluruhan tingkat kecurangan akademik yang terjadi. 


\section{DAFTAR PUSTAKA}

Colby, B. 2006. Cheating; What is it (online), (http://clas.asu.edu /files/AI\%20Flier.pdf, diakses tanggal 14 mei 2015).

Herman. 2008. "Pengaruh Keadilan Organisasi dan Sistem Pengendalian Intern Terhadap Kecurangan”.Skripsi. Fakultas Ekonomi Universitas Negeri Padang.

Jogiyanto, H.M. 2004. Metodologi Penelitian Bisinis. Yogyakarta : BPFE

Karni. 2000. Klasifikasi Fraud. (http://berkatzega.blogspot.com/2014/11/tugas-softskill-2kecurangan -fraud.html, diakses tanggal 10 april)

Lambert, E.G., Hogan, N.L.,\&Barton, S.M. 2003. Collegiate academic dishonesty revisited: what have they done it, who does it, and why did theydo it. Electronic Jounal of Sosiology (online) ( http://www.sociology.org /content/vol7.4/lambert etal.html, diakses tanggal 14 mei 2015)

Faisol, Moh. 2013. Akuntansi Forensik dan Fraud Examination, apa dan bagaimana?.Artikel (http://semangadmu.nlogspot.com/2013/10/akuntansi-forensik-dan $\quad$-fraud.html?m=1, diakses tanggal 27 mei 2015).

Muslimah. 2013. "Persepsi Mahasiswa Akuntansi Terhadap Praktik-praktik Kecurangan Akademik ( Akademik Fraud)". Skripsi. Jurusan Akuntansi Fakultas Ekonomi Universsitas Brawijaya, Malang.

Purnamasari. 2013. "Analisis Pengaruh Dimensi Fraud Triangle terhadap Perilaku Kecurangan Akadamik Mahasiswa Pada Saat Ujian dan Metode Pencegahannya”. Skripsi. Jurusan Akuntansi Fakultas Ekonomi Universitas Brawijaya, Malang.

Peraturan Pemerintah Republik Indonesia. Nomor 37 Tahun 2009. Dosen.Jakarta: Kementrian Pendidikan Dan Budaya ( KEMENDIKBUD) Republik Indonesia.

Peraturan Pemerintah Reoublik Indonesia Nomor 53 Tahun 2010. Disiplin Pegawai Negeri Sipil. Jakarta: Kementrian Pendidikan Dan Budaya (KEMENDIKBUD) Republik Indonesia.

Rahmalia,Gugus. 2014. "Perilaku Kecurangan Akademik Mahasiswa: Dimensi Fraud Diamond”. Skripsi Jurusan Akuntansi Fakultas Ekonomi dan Bisinis Universits Brawijaya, Malang.

Riski.2004. Pendorong Terjadinya Fraud .(online). (http://download.portalgaruda .org.pdf, diakses 16 juni 2015).

Sanusi. 2011. Metodologi Penelitian Bisnis. Jakarta: Salemba Empat

Sayyid. 2012. Fraud dan Akuntansi Forensik. Fakultas Syariah dan Ekonomi Islam IAIN, Banjarmasin. 
Sugiyono. 2013. Metode Penelitian Kuantitatif, Kualitatif dan R\&D. Bandung: Alfabeta.

Tuanakotta. 2010. Akuntansi Forensic dan Audit Investigative. Jakarta: Salemba Empat.

Undang-undang Republik Indonesia. Nomor 14 Tahun 2005. Kewajiban dan Larangan Dosen. Jakarta: Kementrian Pendidikan dan Budaya Republik Indonesia.

Bintaro, Wahyu., Purwanto, Edy., Noviyani, Indah, Dyah. 2013. Hubungan Self Regulated Dengan Kecurangan Akademik Mahasiswa. Educational Psycology Journal 2(1) 2013: Jurusan Psikologi Fakultas Ilmu Pendidikan Universitas Negeri Padang. 